\title{
荷重方向の変動を考慮した構造物の最適設計 OPTIMUM STRUCTURAL DESIGN SUBJECT TO EXTERNAL FORCES FROM UNCERTAIN DIRECTIONS
}

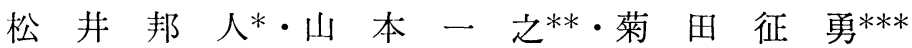 \\ By Kunihito MATSUI, Kazuyuki YAMAMOTO and Yukio KIKUTA
}

\begin{abstract}
A computational method is presented for the optimum design of structures subject to external forces from uncertain directions. Finite element method is used for structural analysis so as to make use of the algorithm for optimizing various types of structures.

As the loading direction changes, the member forces will also vary accordingly. The direction most unfavorable to each member does not necessarily coincide each other. Hence in each member the critical member force and its corresponding direction need to be found before each optimization step. Constraints on stresses, bucklings, dispacements and member sizes are considered. Also presented is the case in which multiple external forces vary their directions independently. Example problems are solved to show the validity of the optimization algorithm.

The concept presented here is useful for the optimum design of towers and marine structures.
\end{abstract}

\section{1.はじめに}

1960 年に発表された L.A. Schmit による構造総合 (Structural Synthesis) に関する論文，またその論文に 続くSchmit および共同研究者による先駆的研究1),2) 以 来, 構造物の最適化に関する研究は数多くなされ, 著し い進歩を遂げてきている.この分野における研究の流れ は，i）最適化アルゴリズムの開発，ii）最適化理論の 利用による構造特性の解明， iii）構造物設計への適用， iv）最適化理論の他分野への応用，に大別できる. 現在 この中で主流をなしているのが，アルゴリズムの開発に 関する研究である. 一方実用的な分野への応用はまだか なり遅れている. 欧米諸国では航空機産業, 自動車産業 において広く最適化手法が取り入れられてはきている が $^{3), 4)}$, 土木工学の分野への適用は大きく立遅れている のが現状である．この原因は実用面においては，土木構 造物は規格化された大量生産品ではないため, 最適化を 行って費用を削減しようとする要求が小さいこと, また

\footnotetext{
* 正会員 $\mathrm{Ph}$. D. 東京電機大学教授 理工学部建設工学科 ( ( 350-03 比企郡鸠山町石坂)

** 正会員 工博 芝浦工業大学助教授 工学部土木工学科

( ( 108 港区芝浦 3-9-14)

*** 正会員 工修 国土舘大学教授 工学部土木工学科
}

( (154 世田谷区世田谷 4-28-1)
一方計算面においては, 設計変数の数が多くなり，その 結果収束性が悪く, 必ずしも最適解が得られない, ある いは得られたとしても計算機の利用経費がかかりすぎ， 全体としてのメリットがなくなることなど考えられる. 最適化理論が構造物の設計へ実際に利用されるようにな るためには, 効率的で, 信頼できかつ汎用性のある最適 化アルゴリズムの開発が必要不可欠である. 効率性に関 しては, 計算機のハードウェアの面でも急速に進歩して おり, 実質的な計算機利用経費の減少に向かっている. また汎用的な最適化のソフトウェアも数多く開発されて きてはいるが, 複雑な諸条件のもとで, 構造物の最適化 を図ることは困難な場合も多い。したがって構造物を最 適化する場合には, 単にその構造物の数学モデルに最適 化のソフトウェアを適用するのではなく，構造物の特性 と与えられた諸条件を十分に利用することが，効率的な 最適化につながってくる. 最近注目されている最適性規 淮法占は, 構造物の特性を十分に考慮した最適化手法と いえるであろう。

本論文においては上記のことを踏まえ, 構造解析法の 特性を生かし, 複雑な荷重条件下の構造物最適化の一手 法を提案している.

構造物の最適化に関する研究はその大多数が, 構造物 に作用する外力を, その大きさ, 方向拉よび作用位置と 
も規定されたものと仮定し, 設計変数および状態変数の 関数系として目的関数, 制約条件式を定義し, 数理計画 法を用いて目的関数の最適化を行っている.しかしなが ら大地に建造される構造物には, 自重, 積載荷重のよう に大きさ, 方向, 作用位置が固定されているもの, 橋梁 に作用する車両荷重のように，大きさ，方向は一定であ るが作用位置の変動するもの, また風荷重, 波浪荷重, 地震荷重のように, 大きさおよび作用位置は等価な静的 荷重と規定されていても，その作用方向が変動するよら な外力がある. 一般に外力の作用位置や方向に変動があ るとき, 構造物の設計は複雑なものとなる. 本研究にお いては, 外力の大きさ, 作用位置は規定されるが, その 作用方向はある範囲内で 変動し得る場合を想定してい る.構造物がそのような荷重の作用を受けるとき, 各節 点変位および個々の部材力は, 荷重方向の変動とともに 変化する. また変位, 部材力が最も撖しい状態, すなわ ち最悪状態となる荷重方向は各節点, 各部材で異なって いる. 従来このような荷重状態で構造物を設計する方法 として, 荷重変動領域内に数個の荷重方向を選定し, 各 荷重方向のもとで構造物を設計し，その中から各荷重に 対し, 各部材断面が最も大きくなる断面をその部材の設 計断面とする考え方, あるいは有限個の方向に作用して いる荷重を荷重群として扱い，最適化の手法を用いて断 面を決定する方法等がある.しかしこれらの方法はどち らも適切にして十分であるとはいえない。さらに，荷重 が複数の節点に作用し，それぞれ独立して荷重方向が変 動する場合には，上述の方法を用いて解決することはほ とんど不可能であろう. 本論文は, 複数の荷重がそれぞ れ独立してその方向を変動する条件のもとで, 構造物の 最適化を図るアルゴリズムを開発し，例題を用いてその 妥当性を検証するものである.

\section{2. 最適化問題}

\section{(1) 問題の定式化}

電子計算機の 出現以来, 構造解析手法が大きく進歩 し, 大部分の構造解析はマトリックス法を用いて定式化 することができる，骨組構造の場合には，その構成部材 相互の位置関係，および各部材の断面量を表わす設計変 数から成る剛性マトリックスにより, 変位を表わす状態 変数と外力ベクトルの関係を表わすことができる.ここ では外力ベクトルの大きさおよび作用位置は規定されて いるが, 作用方向が変動するため, 外力ベクトルは構造 全体座標系に対する角度を表わすパラメーターの関数と なる、構造設計においては, 各部材に生じる応力度は許 容応力度以下であるとともに, 圧縮部材についてはその 座屈応力度以下であり, また構造系の最大変位はあらか じめ与えられた許容值以下である等の制約条件式を満た
さねばならない．これらの制約条件式は設計变数，状態 変数および外力の作用方向を表わすパラメーターの関数 として表現できる.その他設計変数の上限，下限も制約 条件式として考虑している.

いま簡単にするため最適化の尺度となる目的関数とし て, 最も頻繁に用いられる構造物の質量を考えることに すると, 上記の最適化問題は次のような数学モデルで表 わすことができる.

目的関数 $\phi_{0}(\boldsymbol{b})$

剛性方程式

$$
\boldsymbol{K}(\boldsymbol{b}) \boldsymbol{z}=\boldsymbol{Q}(\boldsymbol{a})
$$

制約条件式

$$
\begin{gathered}
\max _{\alpha \in A} \phi_{i}(\boldsymbol{b}, \boldsymbol{z}, \boldsymbol{\alpha}) \leq 0 ., \quad\left(i=1,2, \cdots p_{1}\right) \\
\cdots \cdots \cdots \cdots \cdots \cdots \cdots \cdots \cdots(3) \\
\phi_{i}(\boldsymbol{b}) \leq 0 .,\left(i=p_{1}+1, \cdots p_{2}\right) \cdots \cdots(4) \\
A=\left\{\alpha \mid g_{k}(\boldsymbol{\alpha}) \leq 0 ., k=1,2, \cdots q\right\}
\end{gathered}
$$

ただし, $\boldsymbol{b}=\left\{b_{1}, b_{2}, \cdots b_{\boldsymbol{m}}\right\}^{\boldsymbol{T}}$ は設計変数， $\boldsymbol{z}=\left\{z_{1}, z_{2}, \cdots\right.$ $\left.z_{n}\right\}^{T}$ は状態変数, $\boldsymbol{\alpha}=\left\{\alpha_{1}, \alpha_{2}, \cdots \alpha_{s}\right\}^{T}$ は環境変数, $\boldsymbol{K}(\boldsymbol{b})$ は $n \times n$ の 剛性マトリックス, また $\boldsymbol{Q}(\alpha)$ は外 カベクトルである. 式 (3) は応力, 座屈, 変位に関す る制約条件式を表わしており, 式 (4) は部材断面の上 限, 下限のような設計変数のみからなる制約条件式であ る.な扔式 (3) は $\boldsymbol{\alpha}$ に関するパラメトリックな制約条 件で，ここでは $\boldsymbol{\alpha}$ は外力の方向を表わしており，その 変動領域は式（5）で示される. 式（1）（5）で定義さ れる最適化問題を解くにあたり，式（3）の最大值を求 める必要がある.これはすなわち次に示す式 (6)〜 (8) で定義される最適化問題を解くことに帰着する.

$$
\begin{array}{ll}
\max . \phi_{\boldsymbol{i}}(\boldsymbol{b}, \boldsymbol{z}, \boldsymbol{\alpha}),\left(i=1,2, \cdots p_{1}\right) \cdots \cdots \cdots \cdots \cdots(6) \\
\text { 制約条件式 } \quad \boldsymbol{K}(\boldsymbol{b}) \boldsymbol{z}=\boldsymbol{Q}(\boldsymbol{\alpha}) \cdots \cdots \cdots \cdots \cdots \cdots \cdots \cdots(7) \\
g_{\boldsymbol{k}}(\boldsymbol{\alpha}) \leq 0 .,(k=1,2, \cdots q) \cdots \cdots(8)
\end{array}
$$

上記の最適化問題を副問題とよぶことにする．副問題を 最適化の手法を用いて解くことも可能であるが，効率的 であるとはいい難い，構造解析が微小変形理論に基づい てなされるならば，理論的に副問題の最適解を求める ことは可能である. その詳細については次節に示す. $\phi_{i}(\boldsymbol{b}, \boldsymbol{z}, \boldsymbol{a}),\left(i=1,2, \cdots p_{1}\right)$ を制約条件式 (7), (8) の もとで最大化を行い，そのときのそれぞれの $\max \phi_{i}$ に 対応する $z, a$ を $\bar{z}_{i}, \bar{\alpha}_{i}$, $\left(i=1,2, \cdots p_{1}\right)$ とする. 得られた max. $\phi_{i}, \quad(i=1$, $\left.2, \cdots p_{1}\right)$ を制約条件式と して式（1）を最小化する 過程を最適化の主問題とよ ぶことにする。

\section{(2) 副問題の解法}

Fig. 1 に示すように節 点 $l$ に大きさ $P_{l}$ が作用し

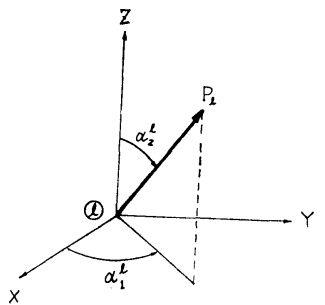

Fig. 1 External Force at Node $l$. 
ているとき，各節点の変位ベクトルを $\boldsymbol{z}^{(l)}$ とする. 全 体座標系において節点 $l$ の $X, Y, Z$ 軸方向に単位荷重 が作用しているとき, 各節点の変位を $z_{1}{ }^{(l)}, z_{2}{ }^{(l)}, z_{3}{ }^{(l)}$ とすると, $P_{l}$ による変位は

$$
\begin{aligned}
z^{(l)}= & P_{l} z_{1}{ }^{(l)} \cos \alpha_{1}{ }^{l} \sin \alpha_{2}{ }^{l}+P_{l} z_{2}{ }^{(l)} \sin \alpha_{1}{ }^{l} \sin \alpha_{2}{ }^{l} \\
& +P_{l} z_{3}{ }^{(l)} \cos \alpha_{2}{ }^{l} \ldots \ldots \ldots \ldots \ldots \ldots \ldots \ldots \ldots \ldots \ldots \ldots \ldots \ldots \ldots \ldots \ldots \ldots \ldots \ldots \ldots \ldots
\end{aligned}
$$

と表わすことができる.さらに複数の節点に外力が作用

しているとき, それらの外力による変位は

$z=\sum_{l \in I} z^{(l)}$

で表わせる．ただし I は外力が作用している節点番号 からなる集合である. 式（3）で表わされる応力，座屈， 変位に関する制約条件は一般に

$$
\begin{aligned}
\max _{\alpha \in A} \phi_{i}(\boldsymbol{b}, \boldsymbol{z}, \boldsymbol{\alpha})= & \sum_{l \in I} \max _{\alpha \in A}\left\{f_{i_{1}}{ }^{l} \cos \alpha_{1}{ }^{l} \sin \alpha_{2}{ }^{l}\right. \\
& +f_{i_{2}}{ }^{l} \sin \alpha_{1}{ }^{l} \sin \alpha_{2}{ }^{l} \\
& \left.+f_{i_{3}}{ }^{l} \cos \alpha_{2}{ }^{l}\right\}-1.0 \leq 0 . \cdots(11)
\end{aligned}
$$

と書き換えることができる. また $f_{i 1}{ }^{l}, f_{i 2}{ }^{l}, f_{i 3}{ }^{l}$ は $z_{1}{ }^{(l)}, z_{2}{ }^{(l)}, z_{3}{ }^{(l)}$ と $P_{l}$ の関数である.上式を整理すれば

$$
\begin{aligned}
& \sum_{l \in I} \max _{\alpha \in A} \sqrt{\left\{\left(f_{i 1}{ }^{l}\right)^{2}+\left(f_{i 2}{ }^{l}\right)^{2}\right\} \sin ^{2}\left(\alpha_{1}{ }^{l}+\theta_{i 1}{ }^{l}\right)+\left(f_{i 3}{ }^{l}\right)^{2}} \\
& \times \sin \left(\alpha_{2}^{l}+\theta_{i 2}^{l}\right)-1.0 \leq 0 \text {. } \\
& \theta_{i 1}{ }^{l}=\arctan \left(\frac{f_{i_{1}}{ }^{l}}{f_{i_{2}}{ }^{l}}\right) \\
& \theta_{i 2}{ }^{l}=\arctan \left(\frac{f_{i 3}{ }^{l}}{\sqrt{\left\{\left(f_{i 1}{ }^{l}\right)^{2}+\left(f_{i 2}{ }^{l}\right)^{2}\right\} \sin ^{2}\left(\alpha_{1}{ }^{l}+\theta_{i 1}{ }^{l}\right)}}\right) \\
& (l \in I)
\end{aligned}
$$

式（12）を最大とすることは，その式の各項を最大とす ることに帰着する. 節点 $l$ に作用している荷重の方向, $\alpha_{1}{ }^{l}$ および $\alpha_{2}{ }^{l}$, の変動領域の上限值, 下限值をそれぞれ $\alpha_{1} U^{l}, \alpha_{1} L^{l}$ および $\alpha_{2} U^{l}, \alpha_{2}{ }^{l}$ とすると, 式 (5) は

$$
\begin{aligned}
& \alpha_{1} L^{l} \leq \alpha_{1}^{l} \leq \alpha_{1} U^{l} \\
& \alpha_{2} L^{l} \leq \alpha_{2}{ }^{l} \leq \alpha_{2} U^{l}
\end{aligned}
$$

となる. 式 (12) を最大とすることは $\sin ^{2}\left(\alpha_{1}{ }^{l}+\theta_{i 1}{ }^{l}\right)$, $\sin \left(\alpha_{2}{ }^{l}+\theta_{i 2}{ }^{l}\right)$ を最大とすることであり，そのときの $\alpha_{1}{ }^{l}, \alpha_{2}{ }^{l}$ をそれぞれ $\alpha_{i_{1}}{ }^{l}, \alpha_{i 2}{ }^{l}$ とする. 式 (15), (16) が全空間を形成する場合, $-\pi<\alpha_{i}{ }^{l} \leq \pi, 0<\alpha_{2}{ }^{l} \leq \pi$ であり, そのとき $\sin ^{2}\left(\alpha_{i_{1}}{ }^{l}+\theta_{i_{1}}{ }^{l}\right), \sin \left(\alpha_{i_{2}}{ }^{l}+\theta_{i_{2}}\right)$ の值 はともに 1.0 となる.このとき式 (12) は

$$
\sum_{l \in I} \sqrt{\left(f_{i 1}{ }^{l}\right)^{2}+\left(f_{i 2}{ }^{l}\right)^{2}+\left(f_{i 2}\right)^{l}}-1.0 \leq 0 \cdots \cdots
$$

と単純化される.

式 (12) を最大とする $\alpha_{i 1}{ }^{l}, \alpha_{i 2}{ }^{l}$ の值は, 一般にそれ ぞれの制約式により異なっている.このことは後述の例 題の結果からも明らかである.このようにして求められ た副問題の解は Kuhn Tucker の必要条件を満たさね ばならない. すなわち式 (6)〜 (8) で定義される最適化 問題のラグランジアンを

$$
L_{i}=-\phi_{i}-\lambda_{i}{ }^{T}(\boldsymbol{K} \boldsymbol{z}-\boldsymbol{Q})+\boldsymbol{\mu}_{i}{ }^{T} \boldsymbol{g}, \quad\left(i=1,2, \cdots p_{1}\right)
$$

$$
\begin{aligned}
& \text { とすると， } \\
& L_{i, \alpha}=-\phi_{i, \alpha}-\lambda_{i}{ }^{T} Q, \alpha+\mu_{i}{ }^{T} g, \alpha=0 . \\
& L_{i, z}=-\phi_{i, z}+\lambda_{i}^{T} K=0 \text {. } \\
& \lambda_{i}{ }^{T}(K z-Q)=0 \text {. } \\
& \mu_{i}^{T} \boldsymbol{g}=0 \text {. }
\end{aligned}
$$

が成立する. $\lambda_{i} \neq 0, \mu_{i} \geq 0,\left(i=1,2, \cdots p_{1}\right)$ はラグラ ンジェ乗数で $\lambda_{i}=\left(\lambda_{i_{1}}, \lambda_{i_{2}}, \cdots \lambda_{i n}\right)^{T}, \mu_{i}=\left(\mu_{i_{1}}, \mu_{i_{2}}, \cdots\right.$ $\left.\mu_{i k}\right)^{T}$ である.またここでは，一般にベクトル変数 $\boldsymbol{x} \in$ $R^{n}$ のスカラー関数 $\phi_{i}(\boldsymbol{x})$ の偏微分形を $\phi_{i, \boldsymbol{x}}$ で表わ す.これは行ベクトル $\left(\frac{\partial \phi_{i}}{\partial x_{1}}, \frac{\partial \phi_{i}}{\partial x_{2}}, \cdots,-\frac{\partial \phi_{i}}{\partial x_{n}}\right)$ を意味 している.

\section{3. 主問題の解法と最適化アルゴリズム}

式 (3) の最大值が求まると, 式 (2)〜 (5) の制約条件 を満たし，目的関数 (1) を最小とする設計変数 $\boldsymbol{b}$ を求 めるのが主問題である.いま $j$ 番目の反復計算後, 設計 変数 $\boldsymbol{b}^{(j)}$ が $\delta \boldsymbol{b}$ だけ変化すると, $\boldsymbol{z}, \boldsymbol{a}$ もそれぞれ $\delta \boldsymbol{z}$,

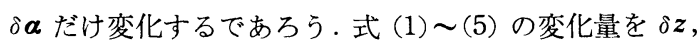
$\delta \boldsymbol{b}, \delta \boldsymbol{a}$ の一次近似で表わすと, 次のようになる.

$$
\begin{aligned}
& \delta \phi_{0}=\boldsymbol{\phi}_{0}, \boldsymbol{b} \delta \boldsymbol{b} \\
& \boldsymbol{K} \delta \boldsymbol{z}+(\boldsymbol{K} \boldsymbol{z}), \boldsymbol{b} \delta \boldsymbol{b}-\boldsymbol{Q}, \boldsymbol{\alpha} \delta \boldsymbol{\alpha}=0 \\
& \max _{\delta \boldsymbol{\alpha}} \delta \phi_{i}=\max _{\delta \boldsymbol{\alpha}}\left(\boldsymbol{\phi}_{i, \boldsymbol{z} \delta} \boldsymbol{z}+\boldsymbol{\phi}_{i, \boldsymbol{b} \delta} \boldsymbol{b}+\boldsymbol{\phi}_{i, \boldsymbol{\alpha}} \delta \boldsymbol{\alpha}\right), \\
& \left(i=1,2, \cdots p_{1}\right) \\
& \delta \phi_{i}=\boldsymbol{\phi}_{i, \boldsymbol{b}} \delta \boldsymbol{b}, \quad\left(i=p_{1}+1, \cdots p_{2}\right) \\
& \delta g_{k}=\boldsymbol{g}_{k, \boldsymbol{\alpha} \delta \boldsymbol{\alpha}}(k=1,2, \cdots q)
\end{aligned}
$$

$\delta \boldsymbol{b}$ は式 (2)〜 (5) を満足する方向で, かつ目的関数式 （1）を小さくするょうに決定する. 式 (3) の不等式制 約条件のうちで, 満足されない制約条件の添字集合を

$$
B_{1}=\left\{i \mid \phi_{i}\left(\boldsymbol{b}^{(j)}, z_{i}, \boldsymbol{\alpha}_{i}\right) \geq 0, i \leq p_{1}\right\}
$$

と定義する．また必要な修正量を $\Delta \phi_{i}$ とすると，一般 に

$$
\Delta \phi_{i}=-\phi_{i}, \quad\left(i \in B_{1}\right)
$$

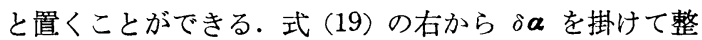
理すると，

$$
\boldsymbol{\phi}_{i, \boldsymbol{\alpha} \delta} \boldsymbol{\alpha}=\left[-\lambda_{i}{ }^{T} \boldsymbol{Q}, \boldsymbol{\alpha}+\boldsymbol{\mu}_{\boldsymbol{i}}{ }^{T} \boldsymbol{g}, \boldsymbol{\alpha}\right] \delta \boldsymbol{\alpha}
$$

となる.また式（20）の右から $\delta \boldsymbol{z}$ を掛け, 式（24）を 用いて整理すると，

$$
\boldsymbol{\phi}_{i, \boldsymbol{z}} \delta \boldsymbol{z}=-\boldsymbol{\lambda}_{i}{ }^{T}[(\boldsymbol{K} \boldsymbol{z}), \boldsymbol{b} \delta \boldsymbol{b}-\boldsymbol{Q}, \boldsymbol{a} \delta \boldsymbol{\alpha}]
$$

となる. 式 (3) において $\boldsymbol{b}$ が $\delta \boldsymbol{b}$ だけ変化するとき, 式（3）の変化量は式（25）で表わされる. 式（3）のう ち集合 $B_{1}$ に属する式だけが，式 (29) に示される量だ け修正される必要があることを考慮して, 式 (30), (31) を式（25）に代入すると，

$$
\begin{aligned}
\max _{\delta \boldsymbol{\alpha}} \delta \phi_{i}= & \max _{\delta \boldsymbol{\alpha}}\left[\left\{\boldsymbol{\phi}_{i, \boldsymbol{b}}-\lambda_{i}{ }^{T}(\boldsymbol{K} \boldsymbol{z}), \boldsymbol{b}\right\} \delta \boldsymbol{b}+\boldsymbol{\mu}_{i}{ }^{T} \boldsymbol{g}, \boldsymbol{\alpha} \delta \boldsymbol{\alpha}\right] \\
& \leq \Delta \phi_{i}, \quad\left(i \in B_{1}\right) \cdots \ldots \ldots \ldots \ldots \ldots \ldots \ldots \ldots \ldots \ldots \ldots \ldots \ldots \ldots \ldots
\end{aligned}
$$




$$
\max _{\delta \boldsymbol{\alpha}}\left[\boldsymbol{\mu}_{i}^{T} \boldsymbol{g}, \boldsymbol{\alpha} \delta \boldsymbol{\alpha}\right] \leq-\left\{\phi_{i, \boldsymbol{b}}-\lambda_{i}^{T}(\boldsymbol{K} \boldsymbol{z}), \boldsymbol{b}\right\} \delta \boldsymbol{b}+\Delta \varphi_{i}
$$

を得る. $\boldsymbol{\mu}_{i} \geq 0, \boldsymbol{\mu}_{i}{ }^{T} \boldsymbol{g}, \boldsymbol{\alpha} \delta \boldsymbol{\alpha} \leq 0$, であるから, 左辺は $\delta \boldsymbol{\alpha}$ $=0$ ，のとき最大となり，その值は 0 である. したがっ $\tau$

$$
\left\{\boldsymbol{\phi}_{i, \boldsymbol{b}}-\boldsymbol{\lambda}_{i}{ }^{T}(\boldsymbol{K} \boldsymbol{z}), \boldsymbol{b}\right\} \delta \boldsymbol{b}-\Delta \phi_{i} \leq 0
$$

となる.このことは設計変数が微小変化しても，応力や 変位を最大とする $\boldsymbol{a}$ の值は, 変わらないことを意味し ている. その結果，副問題では“ $\boldsymbol{b}$ を一定にして” $\boldsymbol{z}, \boldsymbol{a}$ を求め, 主問題では “ $\boldsymbol{a}$ を一定にして” $\boldsymbol{b}$ を求める.こ の過程を繰り返すことにより最適解を得ることができ る.

いま便宜上次のように定義する.

$$
\begin{aligned}
& B_{2}=\left\{i \mid \phi_{i}(\boldsymbol{b}) \geq 0 ., \quad i>p_{1}\right\} \\
& \boldsymbol{l}_{0}=\phi_{0, b} \\
& \boldsymbol{l}_{\boldsymbol{i}}=\boldsymbol{\phi}_{i, \boldsymbol{b}}-\boldsymbol{\lambda}_{\boldsymbol{i}}{ }^{T}(\boldsymbol{K} \boldsymbol{z}), \boldsymbol{b},\left(i \in B_{1}\right) \\
& \boldsymbol{l}_{\boldsymbol{i}}=\boldsymbol{\phi}_{\boldsymbol{i}, \boldsymbol{b}},\left(i \in B_{2}\right) \\
& \tilde{\boldsymbol{l}}=\left\{\boldsymbol{l}_{\boldsymbol{i}} \mid i \in B_{1} \cup B_{2}\right\} \\
& \Delta \tilde{\boldsymbol{\phi}}=\left\{\Delta \phi_{i} \mid i \in B_{1} \cup B_{2}\right\}
\end{aligned}
$$

式（1）（5）で定義された最適化問題を解くことは， 次の問題を解くことに帰着する。

$$
\begin{array}{ll}
\operatorname{minimize} & \delta \phi_{0}=\boldsymbol{l}_{0} \delta \boldsymbol{b} \ldots \ldots \ldots \ldots \\
\text { subject to } & \tilde{\boldsymbol{l}}_{\delta} \boldsymbol{b}-\Delta \tilde{\boldsymbol{\phi}} \leq() . \ldots . \\
& { }_{\delta} \boldsymbol{b}^{T} \boldsymbol{W} \delta \boldsymbol{b}-\xi^{2}=0 .
\end{array}
$$

式 (43) は $\boldsymbol{b}$ の変化量 $\delta \boldsymbol{b}$ が大きくなりすぎないよ うに設けた制約条件である。W は重み行列であり, Fletcher Powell 法の Hesse 行列のように適切に選択する ことにより収束性が向上すると思わ机る。ここではその 件については検討しておらず，単位行列を用いている。 また $\xi^{2}$ は小さな正数である.式 (41)〜 (43) で定義さ れた問題の解は, ラグラジアン

$$
L=\boldsymbol{l}_{0}{ }^{T} \delta \boldsymbol{b}+\tilde{\boldsymbol{v}}^{T}\left(\tilde{\boldsymbol{l}}^{T} \delta \boldsymbol{b}-\Delta \tilde{\boldsymbol{\phi}}\right)+\boldsymbol{r}\left(\delta \boldsymbol{b}^{T} \boldsymbol{W} \delta \boldsymbol{b}-\xi^{2}\right)
$$

と置き, Kuhn-Tucker の必要条件から求めることがで きる6). ただし $\tilde{\boldsymbol{v}}^{T} \geq 0, r \geq 0$ はそれぞれラグランジェ 乗数である.そしてその解は

$$
\delta \boldsymbol{b}=\frac{1}{2 \gamma} \delta \boldsymbol{b}_{1}+\delta \boldsymbol{b}_{2}
$$

で表わすことができる．ただし

$$
\begin{array}{r}
\delta \boldsymbol{b}_{1}=\boldsymbol{W}^{-1}\left(\boldsymbol{l}_{0}+\tilde{\boldsymbol{l}} \tilde{\boldsymbol{v}}_{1}\right) \\
\delta \boldsymbol{b}_{2}=-\boldsymbol{W}^{-1} \tilde{\boldsymbol{l}} \tilde{\boldsymbol{v}}_{2} \ldots \ldots \ldots \ldots
\end{array}
$$

で表わすことができ，また $v_{1}, v_{2}$ はそれぞれ

$$
\begin{aligned}
& \tilde{\boldsymbol{l}}^{T} \boldsymbol{W}^{-1} \tilde{\boldsymbol{l}}_{\boldsymbol{1}}=-\tilde{\boldsymbol{l}}^{T} \boldsymbol{W}^{-1} \boldsymbol{l}_{0} \ldots \\
& \tilde{\boldsymbol{l}}^{T} \boldsymbol{W}^{-1} \tilde{\boldsymbol{l}}_{2}=-\Delta \tilde{\boldsymbol{\phi}} \ldots \ldots \ldots . .
\end{aligned}
$$

の解である. また $\tilde{v}$ と $\tilde{v}_{1}, \tilde{v}_{2}$ の間には

$$
\tilde{\boldsymbol{v}}=\tilde{\boldsymbol{v}}_{1}+2 r \tilde{\boldsymbol{v}}_{2}
$$

の関係がある.
以上に展開した最適化のアルゴリズムを整理すると， 次のようになる.

Step 1. 初期值 $\boldsymbol{b}^{(0)}$ を選定する.

Step 2. 式 (9)より $\boldsymbol{z}_{1}{ }^{(l)}, \boldsymbol{z}_{2}{ }^{(l)}$ ， および $\boldsymbol{z}_{3}{ }^{(l)},(l \in$ I）を計算する.

Step 3. 式 (11) における $f_{i 1}{ }^{l}, f_{i 2}{ }^{l}$ および $f_{i 3}{ }^{l}$, $\left(l \in I, i=1,2, \cdots p_{1}\right)$ を計算する.

Step 4. 式 (12) を最大とする $\theta_{i_{1}}{ }^{l}, \theta_{i_{2}}{ }^{l}, \alpha_{i_{1}}{ }^{l}$ およ び $\alpha_{i 2}{ }^{l}$ を式 (13)〜(16) より求め, また その最大值を計算する.

Step 5. 添字集合 $B_{1} \cup B_{2}$ 䘮求める.

Step 6. 式 (20) より $\lambda_{i},\left(i \in B_{1}\right)$ を求める.

Step 7. 式 (36)〜 (38) より $\boldsymbol{l}_{0}$ および $\boldsymbol{l}_{\boldsymbol{i}}, \quad\left(i \in B_{1} \cup\right.$ $B_{2}$ ）を計算する.

Step 8. 式 (40) 中の $\Delta \tilde{\phi}$ を求める. たとえば $\Delta \phi_{i}$ $=-\phi_{i}, \quad\left(i \in B_{1} \cup B_{2}\right)$

Step 9. 式 (48)，(49) より $\tilde{\boldsymbol{v}}_{1}, \tilde{\boldsymbol{v}}_{2}$ を計算する.

Step 10. 式 (50) で $r$ の值を仮定し， $\tilde{\boldsymbol{v}}$ を求める.も し $\tilde{\boldsymbol{v}}$ の要素の中で負となるものがあれば， それに対忘する添字を $B_{1} \cup B_{2}$ 上り取り除 き, Step 7 に庆る。

Step 11. 式 (46)〜 (47) より $\delta \boldsymbol{b}_{1}, \delta \boldsymbol{b}_{2}$ および $\delta \boldsymbol{b}$ を 补算する.

Step 12. $\quad \boldsymbol{b}^{(j+1)}=\boldsymbol{b}^{(j)}+\delta \boldsymbol{b}$ を計算する．ただし（j） は反復計算の回数を示している.

Step 13. $\left\|\delta \boldsymbol{b}_{1}\right\|,\left|\delta \phi_{0}\right|$ が十分に小さく, すべての制 約条件を満足しているとき, 反復計算を打 ち切る。そうでないときには Step 2 に戻 万.

Step 9 に拉いて $r$ の值を仮定しているが，式 (43)を 用いて $r$ を決定することも可能である.そのためには $\xi^{2}$ の值を前もって決めておく必要がある。本論文における 例題の計算では, 文献 (7), (8) に従い $r$ の值を仮定す る方法を採用した。

上記のアルゴリズムの開発にあたり, 比較的大型な構 造物の最適化も行えることを念頭においている。そのた めには構造解析および感度解析を効率的に行う必要があ る. 構造解析におらいては, 剛性マトリックスの対称性, バンド性を考慮したコレスキー法を用いている．また感 度解析を行うため, 式 (20) を整理すると

$$
K \lambda_{i}=\phi_{i, z}{ }^{T}
$$

と書くことができる.最適解を求めるときには, 満たさ れていない制約式 $\phi_{i},\left(i \in B_{1}\right)$ においてのみ, 感度解析 が必要となり, 一般に最適解に近づくと, 满足されない 制約式の数は少なくなる.すなわち式 (51) の右辺の列 数は少なく，また構造解析で用いたコレスキーマトリッ クスを用いると，効率的に $\lambda_{i},\left(i \in B_{1}\right)$ を計算すること 


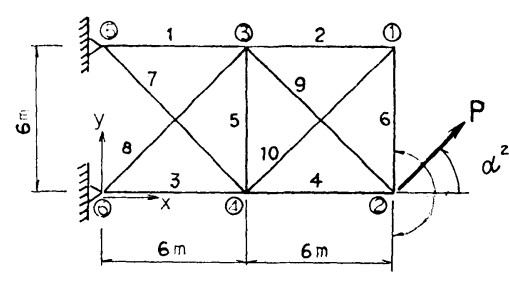

Fig. 2 A 10 Member Truss.

ができる.

\section{4. 数値計算例}

本解析手法の妥当性を検討するため, Fig.

2 に示す 10 部材からなる平面トラス構造に 単一荷重が作用する場合，および Fig. 5 に 示す 25 部材からなる立体トラス構造に複数 荷重が作用する場合の 2 例について, 荷重作用方 向の変動を考慮した最適構造設計の数值解析を行 った.

\section{(1) 10 部材平面トラス構造}

a）本方法を用いた結果

各部材の断面積 $\boldsymbol{b}=\left[b_{1}, b_{2}, \cdots b_{10}\right]^{T}$ を設計変 数とし, 座屈計算に必要な各部材の断面 2 次モー メントは各断面積の 2 乗に比例するものと仮定 し，その比例定数を 1 とした. 荷重状態は節点 (2) に作用する $P=20 \mathrm{tf}(196 \mathrm{kN})$ の集中荷重が，図 に示す変動範囲, すなわち 全体構造座標系の $X$ 軸に対し $-90^{\circ} \sim 90^{\circ}$ の範囲内の角度で変化する ものとした. 設計変数の最小值を $0.1 \mathrm{~cm}^{2}$ とし, 次の 2 種類の制約条件に対して最小質量設計を行 った.

\section{(i) 応力制約条件}

各部材の応力度は, 引張部材については許容軸 方向引張応力度 (1400 kgf/ $\mathrm{cm}^{2}\{137 \mathrm{MPa}\}$ ) 以下 とし，圧縮部材については基準耐荷曲線のかわり にオイラー座屈曲線に対して安全率 1.70 をとっ た值と $1400 \mathrm{kgf} / \mathrm{cm}^{2}\{137 \mathrm{MPa}\}$ との小さい方を 許容軸方向圧縮応力度 $\sigma_{c a}$ とし, 各部材応力度 が許容応力度以下となることを制約条件とした.

本解析法により得られた結果を Table 1 に示 す. Table 1 は各部材に対する最適断面積, 最 小質量, 許容軸方向圧縮応力度および荷重の作用 方向の変動によって生じる各部材の最大圧縮応力 度, 最大引張応力度とそれぞれの荷重作用角度を 示しており, 本解析例の荷重作用方向の変動範 囲内で は, すべての部材断面積は許容軸方向圧縮応力度により 決定されている.Fig. 3 は本解析法で得られた各最適 断面で構成されたトラス構造に対して, 荷重作用方向と そのときの各部材の応力度の関係図を示したもので, 横
Table 1 Optimum 10 Member Truss with Stress Constraints.

\begin{tabular}{c|r|r|r|r|r|r}
\hline Member & $\begin{array}{c}\text { Area }\left(b_{i}\right) \\
\left(\mathrm{cm}^{2}\right)\end{array}$ & $\begin{array}{r}\sigma_{c a} \\
\left(\mathrm{kgf} / \mathrm{cm}^{2}\right)\end{array}$ & $\begin{array}{r}\sigma_{\max . c o m p .} \\
\left(\mathrm{kgf} / \mathrm{cm}^{2}\right)\end{array}$ & \multicolumn{1}{|c|}{$\alpha^{\circ}$} & $\begin{array}{r}\sigma_{\max . t e n s .} \\
\left(\mathrm{kgf} / \mathrm{cm}^{2}\right)\end{array}$ & \multicolumn{1}{|c|}{$\alpha^{\circ}$} \\
\hline 1 & 30.27 & 1025.0 & 1024.9 & 87.5 & 1023.9 & -90.0 \\
2 & 15.29 & 517.8 & 517.4 & 76.1 & 502.3 & -90.0 \\
3 & 29.28 & 991.5 & 990.9 & -90.0 & 1177.5 & 57.3 \\
4 & 19.08 & 646.1 & 645.8 & -90.0 & 1147.5 & 34.2 \\
5 & 10.22 & 346.0 & 346.0 & -22.1 & 130.2 & 90.0 \\
6 & 15.29 & 517.8 & 517.4 & 76.1 & 502.3 & -90.0 \\
7 & 27.44 & 464.6 & 464.4 & 90.0 & 469.8 & -81.3 \\
8 & 30.30 & 513.0 & 513.0 & -90.0 & 517.0 & 82.9 \\
9 & 32.09 & 543.3 & 543.0 & 90.0 & 549.4 & -81.2 \\
10 & 25.33 & 428.9 & 428.8 & -90.0 & 441.7 & 76.1 \\
\hline
\end{tabular}

Optimum Mass $1329 \mathrm{~kg}$

$\sigma_{c a}:$ the smaller of $1400 \mathrm{kgf} / \mathrm{cm}^{2}$ and Euler buckling stress $/ 1.70$

$1 \mathrm{kgf} / \mathrm{cm}^{2}=98.0665 \mathrm{kPa}$

$\sigma_{\text {max.comp. }}$ : maximum compressive stress

$\sigma_{\text {max.tens. }}:$ maximum tensile stress

Table 2 Optimum 10 Member Truss with Stress and Displacement Constraints.

(a) Optimum Design Variables, Maximum Compressive and Tensile Stresses

\begin{tabular}{|c|c|c|c|c|c|c|}
\hline Member & $\underset{\left(\mathrm{cm}^{2}\right)}{\operatorname{Area}\left(b_{i}\right)}$ & $\begin{array}{c}\sigma_{c a} \\
\left(\mathrm{kgf} / \mathrm{cm}^{2}\right)\end{array}$ & $\begin{array}{c}\sigma_{\max } \operatorname{comp} \operatorname{com}^{2} . \\
\left(\mathrm{kgf} / \mathrm{cm}^{2}\right)\end{array}$ & $\alpha^{\circ}$ & $\begin{array}{c}\sigma_{\max } \text { tens. } \\
\left(\mathrm{kgf} / \mathrm{cm}^{2}\right)\end{array}$ & $\alpha^{\circ}$ \\
\hline 1 & 37.10 & 1256.3 & 842.0 & 88.0 & 841.5 & -90.0 \\
\hline 2 & 14.53 & 492.2 & 492.2 & 79.5 & 483.9 & -90.0 \\
\hline 3 & 37.17 & 1258.9 & 774.3 & -90.0 & 926.1 & 56.7 \\
\hline 4 & 26.58 & 900.3 & 487.8 & -90.0 & 855.8 & 34.7 \\
\hline 5 & 9.40 & 318.3 & 318.3 & -35.8 & 186.3 & 90.0 \\
\hline 6 & 14.53 & 492.2 & 492.2 & 79.5 & 483.9 & -90.0 \\
\hline 7 & 27.09 & 458.6 & 458.6 & 90.0 & 462.3 & -82.8 \\
\hline 8 & 30.61 & 518.3 & 518.2 & -90.0 & 520.8 & 84.3 \\
\hline 9 & 32.91 & 557.2 & 557.2 & 90.0 & 560.1 & -84.2 \\
\hline 10 & 24.24 & 410.4 & 410.4 & -90.0 & 417.4 & 79.5 \\
\hline
\end{tabular}

Optimum Mass $1421 \mathrm{~kg}$

$\sigma_{c a}:$ the smaller of $1400 \mathrm{kgf} / \mathrm{cm}^{2}$ and Euler buckling stress $/ 1.70$ $1 \mathrm{kgf} / \mathrm{cm}^{2}=98.0665 \mathrm{kPa}$

$\sigma_{\max }$ comp. : maximum compressive stress

$\sigma_{\text {max.tens. }}:$ maximum tensile stress

(b) Extrome Values of Displacements

\begin{tabular}{|c|c|c|c|c|c|c|}
\hline Node & Displacement & $\delta_{1 \mathrm{~cm} \text { it }}$ & $\delta_{\max }(\mathrm{cm})$ & $\alpha^{\circ}$ & $\begin{array}{l}\delta_{\mathrm{min}} \\
(\mathrm{cm})\end{array}$ & $\alpha^{\circ}$ \\
\hline \multirow{2}{*}{1} & $u_{1}$ & \pm 0.500 & 0.379 & -90.0 & -0.380 & 84.8 \\
\hline & $v_{1}$ & \pm 1.500 & 1.360 & 75.7 & -1.318 & -90.0 \\
\hline \multirow{2}{*}{2} & $u_{2}$ & \pm 0.500 & 0.500 & 46.2 & -0.361 & -90.0 \\
\hline & $v_{2}$ & \pm 1.500 & 1.500 & 76.1 & -1.456 & -90.0 \\
\hline \multirow{2}{*}{3} & $u_{3}$ & \pm 0.500 & 0.240 & -90.0 & -0.241 & 88.0 \\
\hline & $v_{3}$ & \pm 1.500 & 0.538 & 85.9 & -0.537 & -90.0 \\
\hline \multirow{2}{*}{4} & $u_{4}$ & \pm 0.500 & 0.265 & 56.7 & -0.221 & -90.0 \\
\hline & $v_{4}$ & \pm 1.500 & 0.496 & 77.0 & -0.483 & -90.0 \\
\hline
\end{tabular}

$u_{i}$ : displacement in the direction of $x$ axis at node $i$

$v_{i}$ : displacement in the direction of $y$ axis at node $i$

軸に荷重作用方向の $X$ 軸に対する角度を, 縦軸に部材 応力度をとり, 荷重作用方向の変動に対する各部材の応 力の影響線を表わしている. 図中丸印は各部材の断面算 定の基礎となる最大応力度を示しており，それらは各部 材の許容軸方向圧縮応力度と一致しており, 本解析手法 

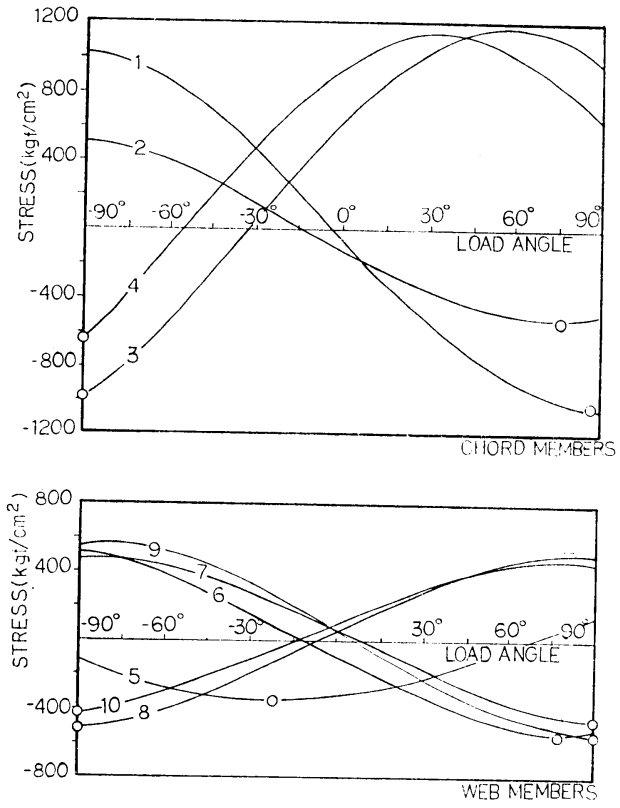

Fig. 3 Stress Iufluence Lines for $10 \mathrm{Member}$ Truss (Stress Constraints).

の妥当性を示しでいる.

（ii）応力制約条件と変位制約条件

态力制約と,最大変位の制約として $X$ 軸方向に \pm 0.5 $\mathrm{cm}, Y$ 軸方向に $\pm 1.5 \mathrm{~cm}$ の変位制約の条件のもとで 構造物の最適化を行った. Table 2 (a) に各部材に対 する最適断面積, 最小質量, 許容軸方向圧縮応力度打上 び荷重の作用方向の変動により生じる各部材の最大圧縮 忘力度, 最大引張応力度とその上きのそれぞれの荷重作 用方向を, Table 2 (b) に各節点に生じる最大変位と そのときの荷重作用方向を示寸. Fig. 4 は荷重の作用 方向と各部材応力度の関係図で, 态力の制約条件以外に 変位の制約条件があるため, 弦材に相当する $1 \sim 4$ 部材 の応力度は許容応力度以下となり, 応力に関しては余裕 のある断面となっているが，腹材に相当する 6 個の部材の断面算定の基礎となる最大応力 度は, すべて各部材の許容軸方向圧縮応力度 と一致する結果が得られ，構造系全体の剛性 に関係する変位制約に対しては腹材は弦材に 比較して，それほど大きな影響を与えないこ とを示している.

\section{b）他の方法との比較}

荷重方向の変動領域内に，等間隔に 5 個の 荷重方向を考え，次に示寸近似解法 1 および 近似解法 2 により 10 部材トラスの断面決定 を行った.

\section{(i) 近似解法 1}

5 個の各荷重方向で，それぞれ忘力制約を
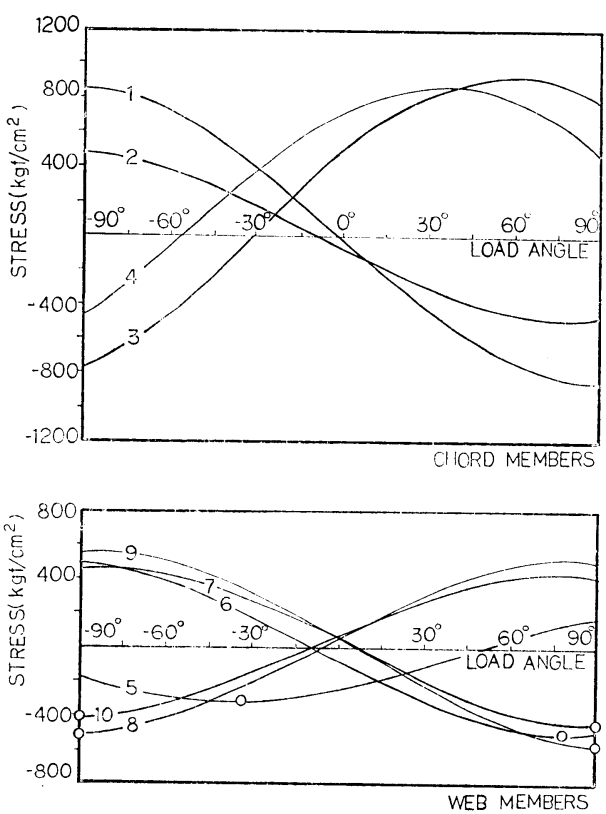

Fig. 4 Stress Iufluence Lines for 10 Member Truss (Stress and Displacement Constraints).

Table 3 Optimum Design for a 10 Member Truss at a Specified Direction of Force.

\begin{tabular}{c|r|r|r|r|r|r}
\hline \multirow{2}{*}{ Member } & \multicolumn{7}{|c|}{ Area $\left(b_{i}\right)\left(\mathrm{cm}^{2}\right)$} \\
\cline { 2 - 7 } & $\alpha=90^{\circ}$ & $\alpha=45^{\circ}$ & $\alpha=0^{\circ}$ & $\alpha=-45^{\circ}$ & $\alpha=-90^{\circ}$ & $b_{i \text { m x }}$ \\
\hline 1 & 31.49 & 28.44 & 0.83 & 20.14 & 28.50 & 31.49 \\
2 & 13.63 & 4.86 & 0.83 & 0.10 & 0.12 & 13.63 \\
3 & 18.87 & 20.84 & 14.27 & 1.62 & 24.36 & 24.36 \\
4 & 11.10 & 24.04 & 14.27 & 0.10 & 24.20 & 24.20 \\
5 & 0.10 & 0.10 & 1.17 & 0.10 & 0.10 & 1.17 \\
6 & 13.63 & 4.86 & 0.83 & 0.10 & 0.12 & 13.63 \\
7 & 23.16 & 8.60 & 0.10 & 0.10 & 0.10 & 23.16 \\
8 & 15.64 & 23.69 & 0.10 & 34.26 & 40.77 & 40.77 \\
9 & 33.85 & 33.38 & 0.10 & 14.20 & 20.04 & 33.85 \\
10 & 6.35 & 0.81 & 0.10 & 2.74 & 3.69 & 6.35 \\
\hline Optimum & 945 & 834 & 154 & 446 & 795 & 1204 \\
\hline Mass kg & & & & & & \\
\hline
\end{tabular}

Table 4 Maximum Tensile and Compressive Stresses (Approximation Method 1).

\begin{tabular}{|c|c|c|c|c|c|c|}
\hline Member & $\underset{\left(\mathrm{kgf} / \mathrm{cm}^{2}\right)}{\sigma_{\max }}$ & $\alpha^{\circ}$ & $\underset{\left(\mathbf{k g f} / \mathrm{cm}^{2}\right)}{\sigma_{\max }} \operatorname{com} \mathbf{p}$. & $\alpha^{\circ}$ & $\left(\begin{array}{c}\sigma_{c a} a \\
\left(\mathrm{kgf} / \mathrm{cm}^{2}\right.\end{array}\right)$ & $\sigma_{\max \cdot \operatorname{comp}} / \sigma_{c a}$ \\
\hline 1 & 1115.1 & -90.0 & 1115.2 & 89.1 & 1066.4 & 1.05 \\
\hline 2 & 311.5 & -90.0 & 311.9 & 87.1 & 461.6 & 0.68 \\
\hline 3 & 1296.1 & 52.0 & 1021.6 & -90.0 & 824.9 & 1.24 \\
\hline 4 & 1044.4 & 38.5 & 650.9 & -90.0 & 819.6 & 0.79 \\
\hline 5 & 545.3 & 90.0 & 864.3 & -39.1 & 39.7 & 21.77 \\
\hline 6 & 311.5 & -90.0 & 311.9 & 87.1 & 461.6 & 0.68 \\
\hline 7 & 300.4 & -83.3 & 298.4 & 90.0 & 392.1 & 0.76 \\
\hline 8 & 524.7 & 87.8 & 524.3 & -90.0 & 690.3 & 0.76 \\
\hline 9 & 658.4 & -89.2 & 658.3 & 90.0 & 573.1 & 1.15 \\
\hline 10 & 946.1 & 87.1 & 944.9 & -90.0 & 107.6 & 8.78 \\
\hline
\end{tabular}

$\sigma_{c a}:$ the smaller of $1400 \mathrm{kgf} / \mathrm{cm}^{2}$ and Euler buckling stress $/ 1.70$

$1 \mathrm{kgf} / \mathrm{cm}^{2}=98.0665 \mathrm{kPa}$

$\sigma_{\text {max.tens. }}:$ maximum tensile stress

$\sigma_{\text {max.comp. }}:$ maximum compressive stress 
満足するといら条件のもとで, 構 造物の最小質量設計を行った。 そ の結果は Table 3 に示されてい る. 各部材断面積沈荷重方向によ り異なっており，各部材について おのおの最も大きな断面を，その 部材の設計断面積とする (Table 3).このようにして得られた構造 物の質量は $1204 \mathrm{~kg}$ である.この 構造物が-90〜 $90^{\circ}$ の間で連続的 に変動する荷重を受けるとき, 各 部材の最大引張応力, 最大圧縮応 力およびそれらの応力值を生じる 荷重方向は Table 4 に示寸とお りである. 引張応力に対して, す べての断面は余裕があるが，圧縮応 力に関しては，必ずしも余裕がある わけではなく, 中には許容值の 20 倍を越える部材があり，このような 考え方による設計が非常に危険とな る可能性があることを示している.

(ii) 近似解法 2

近似解法 1 と同様の荷重状態によ る応力制約条件を同時に満足し，か つ構造物質量を最小にするように， 最適化プログラムを用い断面を決定 したそその結果は Table 5 に示す と扔りである.さらにその断面で構 成される構造物が $-90^{\circ} \sim 90^{\circ}$ の範 囲で連続的に方向を変動する荷重を 受けるとき，各部材に生じる最大引 張応力, 最大圧縮応力とそれらの值 を与える荷重方向も闹表に記されて いる.

\section{（2） 25 部材立体トラス構造}

Fig. 5 に示す構造は, 25 部材か らなる送電線支持用の鉄塔で京る。 荷重状態は節点 (3) と節点 (4) に作用 する集中荷重 $P=100 \mathrm{tf}\{981 \mathrm{kN}\}$ が それぞれ独立に 3 次元空間内を任意 の荷重作用角度で変動し得るものと

し，10 部材トラス構造と同様の応力拘束条件のもとで 最小質量設計を行うと Table 6 の結果が得られた。最 適化にあたって構造物の対称性を考虑し，対称性を保有 する設計変数はリンクして同一グループとして取り扱っ ており，25 部材を 7 グループに分割している。この例 題では，ほとんどの部材が，許容圧縮応力あるいは座屈
Table 5 Optimum Design Variables, Maximum Compressive and Tensile Stresses (Approximation Method 2).

\begin{tabular}{|c|c|c|c|c|c|c|c|}
\hline Member & $\begin{array}{c}\operatorname{Area}\left(b_{i}\right) \\
\left(\mathrm{cm}^{2}\right)\end{array}$ & $\sigma_{\max }^{\sigma_{\operatorname{mans}}}$. & $\alpha^{\circ}$ & $\begin{array}{c}\sigma_{\max }^{\max } \operatorname{comp} . \\
\left(\mathrm{kgf} / \mathrm{cm}^{2}\right)\end{array}$ & $\alpha^{\circ}$ & $\left(\begin{array}{c}\sigma c a \\
\left.\mathrm{kgf} / \mathrm{cm}^{2}\right)\end{array}\right.$ & $\sigma_{\mathrm{max} \cdot \operatorname{comp} \cdot / \sigma_{c a}}$ \\
\hline 1 & 30.27 & 1025.2 & -90.0 & 1026.2 & 87.5 & 1025.2 & 1.00 \\
\hline 2 & 15.01 & 508.5 & -90.0 & 523.4 & 76.3 & 508.5 & 1.03 \\
\hline 3 & 29.24 & 1178.1 & 57.2 & 990.4 & -90.0 & 990.4 & 1.00 \\
\hline 4 & 19.11 & 1148.9 & 34.3 & 647.1 & -90.0 & 647.1 & 1.00 \\
\hline 5 & 9.73 & 136.6 & 90.0 & 356.6 & -22.5 & 329.5 & 1.08 \\
\hline 6 & 15.01 & 508.5 & -90.0 & 523.4 & 76.3 & 508.5 & 1.03 \\
\hline 7 & 27.36 & 468.5 & -81.5 & 463.3 & 90.0 & 463.3 & 1.00 \\
\hline 8 & 30.36 & 517.9 & 83.1 & 514.1 & -90.0 & 514.1 & 1.00 \\
\hline 9 & 32.14 & 550.3 & -81.4 & 544.2 & 90.0 & 544.2 & 1.00 \\
\hline 10 & 25.25 & 440.1 & 76.3 & 427.6 & -90.0 & 427.6 & 1.00 \\
\hline
\end{tabular}

$\sigma_{c a}:$ the smaller of $1400 \mathrm{kgf} / \mathrm{cm}^{2}$ and Euler buckling stress $/ 1.70$

$1 \mathrm{kgf} / \mathrm{cm}^{2}=98.0665 \mathrm{kPa}$

$\sigma_{\text {max.tens. }}$ : maximum tensile stress

$\sigma_{\text {max.comp. }}:$ maximum compressive stress

Table 6 Optimum 25 Member Truss with Stress Constraints.

\begin{tabular}{|c|c|c|c|c|c|c|c|c|}
\hline Group & Member & $\underset{\left(\mathrm{cm}^{2}\right)}{\operatorname{Area}\left(b_{i}\right)}$ & $\begin{array}{c}\sigma_{c a} \\
\left(\mathrm{kgf} / \mathrm{cm}^{2}\right)\end{array}$ & $\underset{\left(\mathrm{mgf} / \mathrm{cm}^{2}\right)}{\sigma_{\max }}$ & $\alpha_{2}{ }^{3 \circ}$ & $\alpha_{1}{ }^{30}$ & $\alpha_{2}{ }^{40}$ & $\alpha_{1^{4}}{ }^{\circ}$ \\
\hline 1 & 1 & 66.15 & 1400 & 1400 & 73.2 & -180.0 & 73.2 & 0.0 \\
\hline \multirow{4}{*}{2} & 2 & \multirow{4}{*}{93.14} & \multirow{4}{*}{1400} & 1400 & 97.5 & -122.9 & 106.7 & 173.7 \\
\hline & 3 & & & 1400 & 106.7 & 6.3 & 97.5 & -57.1 \\
\hline & 4 & & & 1400 & 97.5 & 122.9 & 106.7 & -173.7 \\
\hline & 5 & & & 1400 & 106.7 & -6.3 & 97.5 & 57.1 \\
\hline \multirow{4}{*}{3} & 6 & \multirow{4}{*}{95.41} & \multirow{4}{*}{1400} & 1400 & 73.3 & -173.7 & 115.9 & -116.0 \\
\hline & 7 & & & 1400 & 73.3 & 173.7 & 115.9 & 116.0 \\
\hline & 8 & & & 1400 & 115.9 & -64.0 & 73.3 & -6.3 \\
\hline & 9 & & & 1400 & 115.9 & 64.0 & 73.3 & 6.3 \\
\hline \multirow{4}{*}{4} & 10 & \multirow{4}{*}{5.50} & \multirow{4}{*}{1324} & 1324 & 130.4 & 0.0 & 84.9 & 0.0 \\
\hline & 11 & & & 1324 & 84.9 & -180.0 & 130.4 & -180.0 \\
\hline & 12 & & & 1148 & 113.9 & -70.3 & 113.9 & -109.7 \\
\hline & 13 & & & 1148 & 113.9 & 70.3 & 113.9 & 109.7 \\
\hline \multirow{4}{*}{5} & 14 & \multirow{4}{*}{31.42} & \multirow{4}{*}{1297} & 1297 & 113.4 & -53.5 & 90.8 & -48.1 \\
\hline & 15 & & & 1297 & 113.4 & 53.5 & 90.8 & 48.1 \\
\hline & 16 & & & 1297 & 90.8 & -131.9 & 113.4 & -126.5 \\
\hline & 17 & & & 1297 & 90.8 & 131.9 & 113.4 & 126.5 \\
\hline \multirow{4}{*}{6} & 18 & \multirow{4}{*}{47.01} & \multirow{4}{*}{1400} & 1400 & 64.5 & 152.1 & 115.5 & -112.3 \\
\hline & 19 & & & 1400 & 115.5 & -67.7 & 64.5 & 27.9 \\
\hline & 20 & & & 1400 & 64.5 & -152.1 & 115.5 & 112.3 \\
\hline & 21 & & & 1400 & 115.5 & 67.7 & 64.5 & -27.9 \\
\hline \multirow{4}{*}{7} & 22 & \multirow{4}{*}{143.78} & \multirow{4}{*}{1400} & 1400 & 117.2 & 39.0 & 92.9 & 47.3 \\
\hline & 23 & & & 1400 & 117.2 & -39.0 & 92.9 & -47.3 \\
\hline & 24 & & & 1400 & 92.9 & 132.7 & 117.2 & 141.0 \\
\hline & 25 & & & 1400 & 92.9 & -132.7 & 117.2 & -141.0 \\
\hline
\end{tabular}

Optimum Mass $5407 \mathrm{~kg}$

$\sigma_{c a}:$ the smaller of $1400 \mathrm{kgf} / \mathrm{cm}^{2}$ and Euler buckling stress $/ 1.70$

$1 \mathrm{kgf} / \mathrm{cm}^{2}=98.0665 \mathrm{kPa}$ 


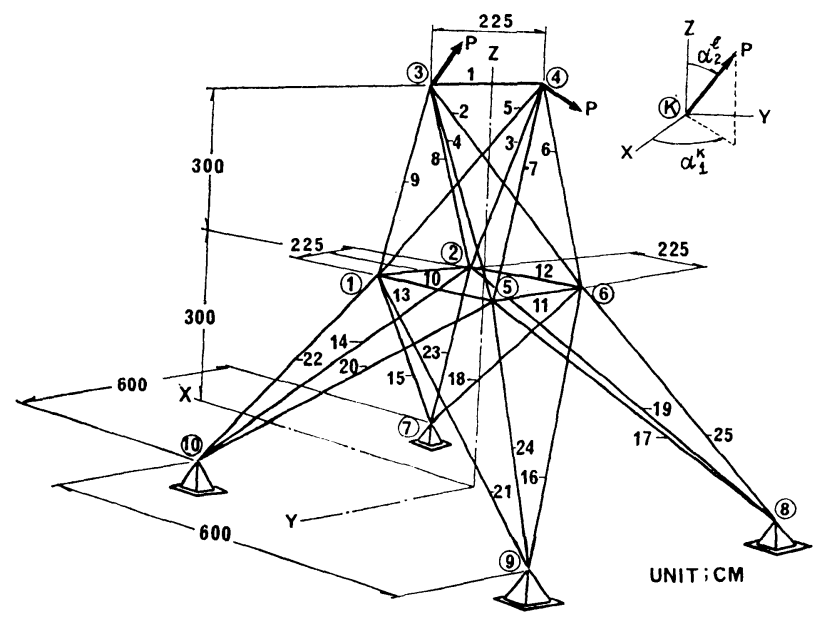

Fig. 5 A 25 Member Truss.

求めることができる.

本研究においては, Rosenの斜影勾配法を用 いているが，非線形計画法の部分を，より効率 的なアルゴリズムで置き換えることにより効率 性の改善を容易に図ることができる。

環境変数 $\boldsymbol{\alpha}$ が荷重方向を示している場合, 2. (2) の副問題の解法で示したように, 応力・ 変位のクリティカルな值を解析的に求めること ができる。しかし移動荷重のように作用点が変 動する場合には，副問題も最適化手法を用いて 解く必要がある. 主問題, 副問題を最適化手法 を用いて解くことは，よほど効率的な最適化手 法を用いないかぎり，困難であろう。

末筆ながら, 東京電機大学の奥村敏恵教授に は，この論文作成にあたり，多くの貴重なご助 言をいただきましたことをここに深く感謝致

なされるが，十分な配虑が必要であろう。

\section{5. むすび}

複数の荷重が，それぞれその方向を変動し得るという 複雑な荷重状態のもとで, 構造物の最適化を行うアルゴ リズムを誘導し，例題を用いその妥当性を示した．本論 文で開発されたアルゴリズムは, 風荷重を受ける鉄塔構 造物や波浪荷重を受ける海洋構造物の設計に適用できる ものと思われる。本研究をまとめると，次のようにな る.

（1）本論文で定義されている最適化問題は，副問題 と主問題に 分離でき, 副問題では設計変数を一定とし て, また主問題では環境変数を一定として扱ってよいこ とを，理論的に示した。

（2）近似解法 1 の考え方は，十分に注意をして用い ないと，危険な設計となること，また近似解法 2 は，比 較的よい近似解を与えている．精度を増すためには考虑 する荷重方向を増やせばよい。

（3）計算時間に関しては，近似解法 1 が最も時間が かかり，本解析手法と近似解法 2 は同じ程度であるが， 後者は考虑する荷重方向を増やすと, それに伴い計算時 間も増えてくる.

（4）本解析手法では，複数の荷重がそれぞれ独立し てその作用方向を変動するような複雑な荷重状態の問題 も容易に処理できるが, 近似解法 1 , 近似解法 2 ではほ とんど不可能である。

（5）各部材，各変位でクリティカルとなる荷重方向 の組合せは異なっており, 構造物の複雑さ, 荷重状態の 複雑さのいかんにかかわらず，この荷重方向の組合せを
します。

なお, 本研究の計算には, 東京電機大学計算センター の FACOM M-160 および国土舘大学計算機 センター の Honeywell DPS 8/70 を使用したことを付記すると ともに，利用に際し，お世話になった関係諸氏に感謝致 します。

\section{参 考 文献}

1) Schmit, L.A. : Structural Design by Systematic Synthesis, Proceedings, 2 nd Conference on Electronic Computation, ASCE, New York, pp. 105 122, 1960.

2) Schmit, L.A. and Kicher, T.P. : Structural Synthesis of Systematic Waffle Plate, NASA TN D-1961, Dec., 1962.

3) Lev, O.E. ed. : Structural Optimization, Recent Developments and Applications, ASCE, New York, 1981.

4) Schmidt, L.A. : Structural Synthesis-Its Genesis and Development, AIAA Journal, Vol. 19, No. 10, pp. 1249 1263, Oct. 1981.

5) Kirsch, U. : Optimum Structural Design, McGraw Hill Book Co., New York, 1981.

6) Haug, E.J. and Arora, J.S. : Applied Optimal DesignMechanical and Structural Systems, John Wiley \& Sons, New York, 1979.

7) Arora, J.S. : On Improving Efficiency of an Algorithm for Structural Optimization and a User's Manual for Program Trussopt 3, An Interim Technical Report, Division of Materials Engineering, College of Engineering, The University of Iowa, June 1974 (Revised September 1976).

8) Arora, J.S. and Moh, N.S. : Numerical Aspects and Step-size Selection in Gradient Projection Method for Structural Optimization : Technical Report No. 47, Division of Materials Engineering, College of Engineering, The University of Iowa, January 1979.

(1983.8.1 · 受付) 